J. Clin. Chem. Clin. Biochem.

Vol. 15,1977 , pp. 267-269

\title{
Thin-Layer Chromatography of Guanidino Compounds
}

\author{
By A. Völkl and H. H. Berlet
}

Institut für Pathochemie und Allgemeine Neurochemie (Dir. Prof. Dr. Dr. G. Quadbeck) Universität Heidelberg

(Received September 6/November 26, 1976)

Summary: Twelve guanidino compounds including, among others, glycocyamine, creatine, creatinine, arginine, guanidinosuccinic acid were submitted to thin-layer chromatography on plates precoated with silica gel or cellulose, respectively. Optimal resolution was obtained by two-dimensional chromatography on cellulose layers when the two solvent systems iso-propanol-acetic acid-water (volumes, $60 \mathrm{ml}+45 \mathrm{ml}+15 \mathrm{ml}$ ) and iso-propanol-dimethylformamide-water (volumes, $40 \mathrm{ml}+20 \mathrm{ml}+20 \mathrm{ml}$ ) were used for the first and second dimension, respectively. This procedure permitted the resolution of 10 distinct spots out of a mixture of the twelve guanidino compounds. Chloroform-methanol-ammonia $(170 \mathrm{~g} / \mathrm{kg}$ ) (volumes, $40 \mathrm{ml}+20 \mathrm{ml}+20 \mathrm{ml}$ ) proved to be the most suitable solvent system for one-dimensional chromatography on cellulose layers of less complex mixtures of guanidino compounds.

\section{Dünnschichtchromatographie von Guanidinoverbindungen}

Zusammenfassung: 12 Guanidine, darunter Verbindungen wie Glycocyamidin, Kreatin, Kreatinin, Arginin und Guanidinobernsteinsäure wurden dünnschichtchromatographisch auf Kieselgel bzw. Cellulose getrennt. Zweidimensionale Dünnschichtchromatographie auf Cellulose unter Verwendung von iso-Propanol/Essigsäure/Wasser (Volumina, $60 \mathrm{ml}+45+15 \mathrm{ml}$ ) und iso-Propanol/Dimethylforamid/Wasser (Volumina, $60 \mathrm{ml}+20 \mathrm{ml}+20 \mathrm{ml}$ ) ergab dabei die besten Resultate. 10 von 12 Guanidinen ließen sich mit diesem Verfahren nebeneinander nachweisen. Als bestes Laufmittelsystem für eindimensionale Trennungen weniger komplexer Gemische von Guanidinoverbindungen auf Kieselgel oder Cellulose erwies sich die Kombination Chloroform/Methanol/Ammoniak $(170 \mathrm{~g} / \mathrm{kg})$ (Volumina, $40 \mathrm{ml}+20 \mathrm{ml}+20 \mathrm{ml}$ ).

\section{Introduction}

The separation of guanidino compounds by thin-layer chromatography is dealt with in a number of reports $(1-4)$.

In general the scope of these investigations is restricted to only one or a few guanidino compounds. We have recently carried out a systematic search for conditions suitable for separating complex synthetic mixtures comprising up to 12 different guanidino compounds. These included compounds of physiological or pathophysiological significance and their congeners. Pharmacological agents like hypoglycemic biguanides were not included. Separation methods were based on thin-layer chromatography (5). In addition to the classical partition/adsorption chromatography, these methods also included thin-layer electrophoresis and thin-layer ionexchange chromatography (6).

Straight adsorption/partition chromatography still proved to be the most versatile approach. The following results summarize the most pertinent experimental data of this investigation and describe both a one- and twodimensional chromatographic system which may be used for the rapid screening of unknown samples for the presence of various guanidino compounds.

\section{Materials and Methods}

\footnotetext{
Ascending thin-layer chromatography was carried out according to standard procedures at room temperature and chamber saturation throughout. Commercial thin-layer plates (Merck, Darmstadt) were precoated with silica gel or cellulose of $0.25 \mathrm{~mm}$ thickness.

All guanidino compounds (for list see tab. 1) were of commercial origin (Eastman Organic Chemicals; Schuchardt-Merck; Calbiochem; Fluka), and standard solutions $(2 \mathrm{~g} / \mathrm{l})$ were freshly prepared immediately before chromatography. $2 \mu \mathrm{l}$ of each standard solution, both of single compounds and mixtures of several or all compounds, were spotted onto the plates as a streak of $1 \mathrm{~cm}$ width. Possible interactions between guanidino compounds on the plates regarding migration and resolution were accounted for by comparing chromatograms of individual compounds and mixtures.
} 
Tab. 1. One-dimensional thin-layer chromatography of guanidino compounds on silica gel and cellulose layers, respectively, with chloroform/methanol/ammonia as solvent system.

\begin{tabular}{lll}
\hline Compound & \multicolumn{2}{c}{$\mathrm{R}_{\mathbf{F}}$-values } \\
\cline { 2 - 3 } & Sorbent: Silica gel & Sorbent: Cellulose \\
\hline $\begin{array}{l}\text { N-amidino-benzamide } \\
\text { N-methyl-guanidine }\end{array}$ & $0.95 \pm 0.03(1)^{\mathrm{a}}$ & $0.94 \pm 0.01(1)$ \\
$\quad \mathrm{HCl}$ & $0.05 \pm 0.01(12)$ & $0.65 \pm 0.04(3)$ \\
$\begin{array}{c}\text { Arginine } \\
\text { 2-Amino-4-guanidino- }\end{array}$ & $0.19 \pm 0.01(10)$ & $0.31 \pm 0.05(8)$ \\
$\quad$ butyric acid & & \\
$\quad$ HCl $\cdot \mathrm{H}_{2} \mathrm{O}$ & & \\
2-Amino-3-guanidino- & $0.20 \pm 0.02(9)$ & $0.21 \pm 0.04(12)$ \\
$\quad$ propionic acid $\cdot \mathrm{HCl}$ & & $0.24 \pm 0.03(10)$ \\
$\begin{array}{c}\text { Guanidino-acetic acid } \\
\text { Creatine }\end{array}$ & $0.28 \pm 0.01(8)$ & $0.27 \pm 0.04(9)$ \\
N-amidino-succinic & $0.35 \pm 0.02(6)$ & $0.40 \pm 0.04(6)$ \\
$\quad$ acid & $0.41 \pm 0.04(4)$ & $0.22 \pm 0.06(11)$ \\
$\begin{array}{c}\text { Creatinine } \\
\text { 4-Guanidino-butyric }\end{array}$ & $0.75 \pm 0.04(2)$ & $0.67 \pm 0.04(2)$ \\
$\quad$ acid & $0.39 \pm 0.01(5)$ & $0.41 \pm 0.03(5)$ \\
3-Guanidino-propionic & $0.34 \pm 0.03(7)$ & $0.36 \pm 0.05(7)$ \\
$\quad$ acid
\end{tabular}

a) Order of $R_{F}$-values in descending order. Solvent system: $\mathrm{CHCl}_{3} / \mathrm{CH}_{3} \mathrm{OH} / \mathrm{NH}_{3}(170 \mathrm{~g} / \mathrm{kg})$ $=40 \mathrm{ml}+40 \mathrm{ml}+20 \mathrm{ml} ; \mathrm{pH}=11.56$ $R_{F}$-values are means $\pm S$.D. of 9 runs on silica gel and 10 , on cellulose, respectively.

Solvent systems finally adopted are given in the table and figures, respectively.

Spots were visualized by the following spray reagents in addition to viewing under the UV-lamp where feasible (e. g. creatinine, $\mathrm{N}$-amidino-benzamide):

1. Alkaline picric acid solution for cyclic guanidino compounds (7).

2. Nitroprusside sodium reagent for the demonstration of guanidino carbonic and amino acids (8).

3. Ninhydrin reagent (9) for guanidino amino acids.

\section{Results}

The $R_{F}$-values of a one-dimensional chromatography of guanidino compounds on silica gel and cellulose, respectively, employing the same solvent system chloroform-metharol-ammonia are shown in table 1 . Both sorbents proved to be superior to aluminium oxide or polyamide, as was the solvent system finally chosen from a total of 11 different systems tested (5). As to the migration of guanidino compounds, few differences were noted between cellulose and silica gel, although in general spot size was smaller on the latter, resulting in a slightly better resolution and reproducibility of results, whereas the colors on spraying the plates developed more rapidly and intensely on cellulose layers.

The results of two dimensional runs are shown in figures 1 and 2 and in table 2, the latter listing the numerical $\mathrm{R}_{\mathrm{F}}$-values of the depicted chromatograms. Compared with silica gel, cellulose proved to be definitely superior regarding the overall resolution of 10 out of a mixture

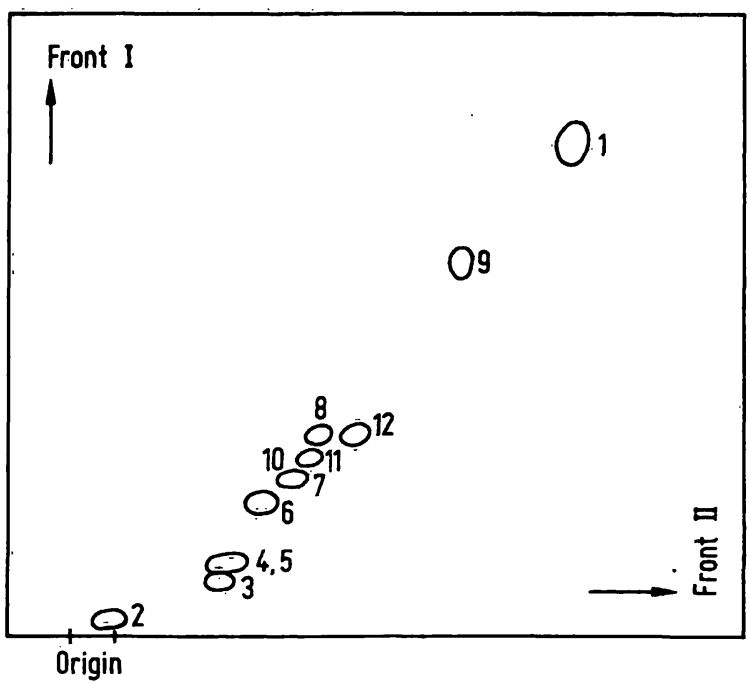

Fig. 1. Two-dimensional thin-layer chromatography of guanidino compounds on silica gel plates.

Solvent systems:

First dimension ( $\mathrm{I}$ ): ethanol $/ \mathrm{H}_{2} \mathrm{O} / \mathrm{NH}_{3}(170 \mathrm{~g} / \mathrm{kg})$ $=90 \mathrm{ml}+10 \mathrm{ml}+20 \mathrm{ml}$

Second dimension (II): $n$-propanol/acetone/ $\mathrm{NH}_{3}$ $(250 \mathrm{~g} / \mathrm{kg}) / \mathrm{H}_{2} \mathrm{O}$

$=50 \mathrm{ml}+20 \mathrm{ml}+40 \mathrm{ml}+10 \mathrm{ml}$

Solvent fronts were allowed to reach $15 \mathrm{~cm}$ from the point of origin. Compounds are numbered according to table 2. Spots were visualized as described.

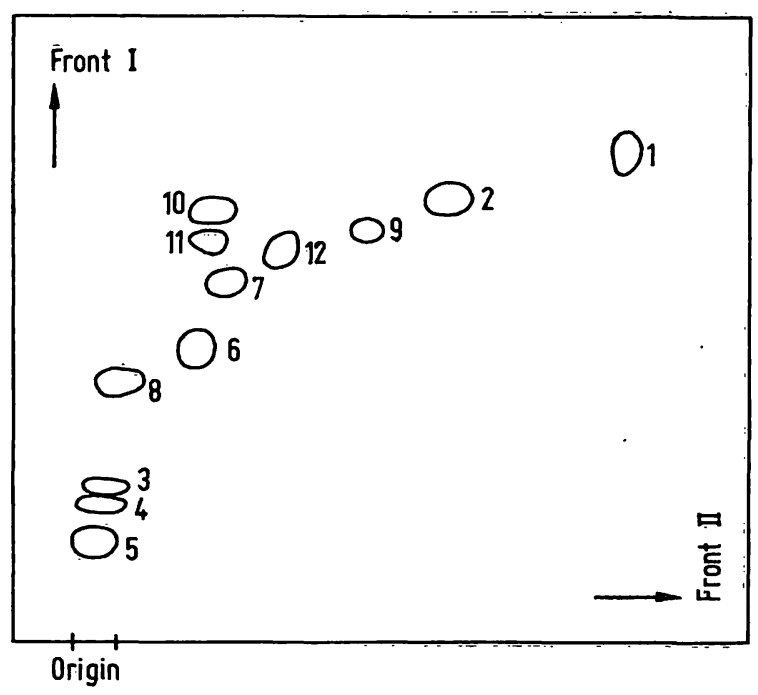

Fig. 2. Two-dimensional thin-layer chromatography of guanidino compounds on cellulose plates.

Solvent systems:

First dimension (III): iso-propanol/acetic acid/ $\mathrm{H}_{2} \mathrm{O}$ $=60 \mathrm{ml}+45 \mathrm{ml}+15 \mathrm{ml}$

Second dimension (IV): iso-propanol/N, N-dimethylformamide $/ \mathrm{H}_{2} \mathrm{O}$ $=60 \mathrm{ml}+20 \mathrm{ml}+20 \mathrm{ml}$

Solvent fronts were allowed to reach $15 \mathrm{~cm}$ from the point of origin. Compounds are numbered according to table 2 . Spots were visualized as described.

of 12 guanidino compounds. It is only amino=guanidinobutyric acid (spot No. 4) and arginine (spot No. 3) which are difficult to distinguish even on celluulose if both are present in an unknown sample. 
Tab. 2. Two-dimensional thin-layer chromatography of guanidino compounds on silica gel and cellulose layers, respectively.

\begin{tabular}{llllll}
\hline Compound & \multicolumn{4}{c}{$\mathrm{R}_{\mathrm{F}}$-values on } \\
& \multicolumn{1}{c}{ Solvent system } & Silica gel & C & Cellulose \\
\cline { 3 - 6 } & & II & III & IV \\
\hline (1) N-amidino-benzamide & 0.79 & 0.73 & 0.77 & 0.81 \\
(2) N-methyl-guanidine $\cdot H C l$ & 0.02 & 0.03 & 0.69 & 0.55 \\
(3) Arginine & 0.09 & 0.18 & 0.23 & 0.02 \\
(4) 2-Amino-4-guanidino-butyric & 0.11 & 0.20 & 0.21 & 0.02 \\
acid $\cdot \mathrm{HCl} \cdot \mathrm{H}_{2} \mathrm{O}$ & & & & \\
(5) 2-Amino-3-guanidino-propionic & 0.11 & 0.20 & 0.15 & 0.01 \\
acid $\cdot \mathrm{HCl}$ & & & & \\
(6) Guanidino-acetic acid & 0.21 & 0.25 & 0.46 & 0.16 \\
(7) Creatine & 0.25 & 0.29 & 0.56 & 0.21 \\
(8) N-amidino-succinic acid & 0.32 & 0.34 & 0.40 & 0.06 \\
(9) Creatinine & 0.59 & 0.55 & 0.65 & 0.41 \\
(10) 4-Guanidino-butyric acid & 0.28 & 0.32 & 0.67 & 0.19 \\
(11) 3-Guanidino-propionic acid & 0.28 & 0.32 & 0.63 & 0.18 \\
(12) N-amidino-alanine & 0.32 & 0.39 & 0.62 & 0.29 \\
\hline
\end{tabular}

a) Solvent systems:

I: Ethanol $/ \mathrm{H}_{2} \mathrm{O} / \mathrm{NH}_{3}(170 \mathrm{~g} / \mathrm{kg})=$

$90 \mathrm{ml}+10 \mathrm{ml}+20 \mathrm{ml} ; \mathrm{pH}=11.32$

II: $n$-Propanol/acetone $/ \mathrm{NH}_{3}(250 \mathrm{~g} / \mathrm{kg}) / \mathrm{H}_{2} \mathrm{O}=$ $50 \mathrm{ml}+20 \mathrm{ml}+40 \mathrm{ml}+10 \mathrm{ml} ; \mathrm{pH}=12.64$

III: iso-propanol/acetic acid/ $/ \mathrm{H}_{2} \mathrm{O}=$ $60 \mathrm{ml}+45 \mathrm{ml}+15 \mathrm{ml} ; \mathrm{pH}=2.07$

IV: iso-propanol $/ \mathrm{N}, \mathrm{N}$-dimethylformamide $/ \mathrm{H}_{2} \mathrm{O}=$ $60 \mathrm{ml}+20 \mathrm{ml}+20 \mathrm{ml} ; \mathrm{pH}=6.30$

$R_{F}$-values are means of duplicate experiments.

\section{Discussion}

The chromatographic results of this study were taken from a large number of experiments in which the two major determinants for the chromatographic behavior of a given compound, i. e. sorbent and solvent system, were tested in different combinations. They were chosen for optimal conditions regarding resolving power towards guanidino compounds and detectability of as many compounds as possible on a single plate run either in one or two dimensions.

Cellulose and silica gel, respectively, were found to be the sorbents best suited for these purposes. Partition of solutes between a stationary and mobile phase prevails as the separating mechanism with these sorbents. Sorbents with marked adsorptive properties, such as aluminium oxide, yielded much less satisfactory results than did polyamide (5). Poor resolution with these sorbents is attributed to strong "adhesive" forces between sorbent and highly polar guanidino compounds.

The three solvent systems were chosen from a total of 11 different mixtures. When their resolving power was compared with solvent properties it turned out that the pH should be either strongly acidic or strongly basic, or that at least the solvents should contain highly polar components (5). Upon plotting $\mathrm{R}_{\mathrm{F}}$-values versus the $\mathrm{pH}$ of solvent systems a consistent interrelationship was observed. The same plots also revealed that other properties of the solvent system were of importance, including ionic strength or solvating power. Only arginine and $\alpha$-amino-guanidino-butyric acid resisted all efforts undertaken to achieve a clear-cut separation. This is obviously due to the extremely close structural resemblance of these compounds, their carbon chain lengths differing by only one atom with otherwise identical substituents.

Aside from more elaborate procedures such as ionexchange column chromatography (10-13), the resolving power of standard methods of thin-layer proved to be equal or even superior to that of electrophoresis and ion-exchange on thin-layer plates; chromatography is, of course, much easier to handle. Thus, by electrophoresis, guanidino compounds are partitioned into basic and acidic groups only, and homologous compounds defy resolution as their charge differences are apparently too small to affect electrophoretic mobility, or they may even be absent altogether in a given buffer system (5). Ion-exchange chromatography on thin-layer plates is limited to specific applications. It enables guanidino compounds closely related to each other, such as 3-guanidino-propionic acid, 4-guanidino-butyric acid, or arginine/2-amino-3-guanidino-propionic acid to be separated. In contrast, other groups of compounds such as arginine/2-amino-4-guanidinobutyric acid or creatine/ glycocyamine/ $\mathrm{N}$-amidino-alanine were not resolved on cation exchange plates (6).

The described methods are now being utilized in evaluating body fluids of uremic subjects.

\section{References}

1. Beyermann, K. \& Wisser, H. (1969), Ż. Anal. Chem. 245, $311-319$.

2. Di Jeso, F. (1968), J. Chromatogr. 32, 269-277.

3. Pataki, G. (1964), Schweiz. Med. Wochenschr. 94, 1789-1790.

4. Rink, M. \& Krebber, D. (1966), J. Chromatogr. 25, 80-86.

5. Völkı, A. (1976), Dissertation, Heidelberg 1976.

6. Völkl, A. \& Berlet, H. H. (1975), J. Chromatogr. 115, 485-492.

7. Jaffé, M. (1886), Hoppe=Seyler's Z. Physịol. Chem. 10, 391.

8. Sakaguchi, S. (1925), J. Biochem. (Tokyo) 5, 25-31.

9. Toennis, G. \& Kolb, J. J. (1951), Anal. Chem. 23, 832.

10. Adams, W. S., Davis, F. W. \& Hansen, L. E. (1964), Anal. Chem. 36, 2209-2211.

11. Natelson, S., Stein, J. \& Bonas, J. E. (1964), Clin. Chem. (Winston Salem, N.C.) 10, 657.

12. Wong, T. (1969), Anal. Biochem. 27, 218-230.

13. Burtis, C. A. \& Warren, K. S. (1968), Clin. Chem. (Winston Salem, N.C.) 14, 290-301.

Dr. A. VölkI

Department of Cell Biology and Cell Pathology

Philipps University Marburg

Robert-Koch-Straße 6

D-3550 Marburg/Lahn 

.

"

. 